\title{
Exploration on Teaching Reform in Mechanical Engineering English
}

\author{
Chun-ling Li \\ School of Mechanical and Automotive Engineering Qilu University of Technology, Shandong Province, China
}

\begin{abstract}
To improve effectively the teaching effect and quality, some problems existing in mechanical engineering English teaching are discussed and analyzed in detail. The students' learning facts and evaluation methods and teachers' ability are the most common problems found in many universities of our country. Several ideas for mechanical engineering English teaching reform were put forward according to the current teaching situation. Some ideas such as improving teaching methods and students' learning initiative have been adopted in teaching practice and the teaching effect is very good. The comprehensive appraisal method has been tried for 2 years. Facts proved that there should be changed from examination-oriented education to quality-orientated education.
\end{abstract}

Index Terms - mechanical, special English, teaching reform.

\section{Introduction}

With the rapid development of science and technology, the information era has come in the world today. There appear more and more international communication and cooperation. English assumes even greater importance. Especially after China's accession to WTO, the social requirement for mechanical talents becomes higher and higher. They are not only required to have a solid special knowledge, but also have certain special English level. That is to say they can communicate mechanical special information in English. So mechanical special English is more and more important for technical personnel of mechanical engineering. There are differences between special English and college English, also they are closely linked[1]. College English is the basis of special English. In college English study, students should enlarge their vocabulary and increase reading to improve their English ability. College Engilsh teaching centers around cultivating highly-qualified personnel with full abilities of listening, speaking, reading, writing, and translating. Special English teaching focused on improving students' ability of reading and translating English materials. So there exists difference between special English and college English in teaching and learning[2].

For our mechanical undergraduate education, special English is arranged in the fifth to the seventh semester generally. So special English is the continuation of college English. In principle, specialised teachers should instruct special English[9]. Now national or regional textbooks are few. Many textbooks are fragments of original special literature or books together. Some textbooks are self-compiled lecture sheets. These textbooks are short of systematicness. Many students think that there are too many special vocabularies and the sentences are too long in these textbooks. So they are afraid of learning special English. At the same time, many teachers who are taking mechanical special English are not familiar with language teaching approach[10]. Also their spoken English is not very good and their pronunciation are not standard. So the situation of mechanical special English is worrying.

\section{Problems in Mechanical Engineering English Teaching}

\section{A. Faculty Problems}

Most teachers who teach mechanical special English are young. Although their English level is high and special knowledge is very solid, they lack experience in essential English teaching. It is difficult for them to achieve special English teaching requests[11].

\section{B. Learning Problems for Some Students}

All the students studied college English for the first two years after they entered the university. Most students can pass CET4. This helps to learn special English. But some students are preparing for the postgraduate entrance examination, they can't study special English hard. Their goal is to pass the final examination[12]. The questionnaire about special English learning of students in our school over the last two years is shown in Table 1.

Table 1. The questionnaire on English learning in our school

\begin{tabular}{|c|c|c|c|}
\hline \multirow{2}{*}{ Questions } & Grade & \multicolumn{2}{|c|}{ Percentage } \\
\cline { 3 - 4 } & & 2013 & 2014 \\
\hline \multirow{3}{*}{$\begin{array}{c}\text { Difficulty in } \\
\text { learning } \\
\text { Special } \\
\text { English }\end{array}$} & Poor listening & $41 \%$ & $37 \%$ \\
\cline { 2 - 4 } & Poor speaking & $32 \%$ & $35 \%$ \\
\cline { 2 - 4 } & Less vocabulary & $30 \%$ & $26 \%$ \\
\cline { 2 - 4 } & Poor grammar & $36 \%$ & $32 \%$ \\
\hline \multirow{4}{*}{$\begin{array}{c}\text { Job } \\
\text { requirements }\end{array}$} & Poor writing & $39 \%$ & $37 \%$ \\
\cline { 2 - 4 } & Oral communication & $78 \%$ & $80 \%$ \\
\cline { 2 - 4 } & Reading literature & $68 \%$ & $71 \%$ \\
\cline { 2 - 4 } & Passing CET-4 & $82 \%$ & $85 \%$ \\
\hline \multirow{3}{*}{$\begin{array}{c}\text { The final } \\
\text { objectives }\end{array}$} & Comprehensive application & $80 \%$ & $83 \%$ \\
\cline { 2 - 4 } & Promoting the specialty ability & $74 \%$ & $78 \%$ \\
\cline { 2 - 4 } & Passing the final examination & $90 \%$ & $93 \%$ \\
\cline { 2 - 4 } & Communication in English & $57 \%$ & $61 \%$ \\
\cline { 2 - 4 } & Better employment & $79 \%$ & $83 \%$ \\
\hline
\end{tabular}

Table 1 shows many students are poor in listening, speaking, writing and grammar. Special English will be used in many jobs. So many students study hard English to get a good job. But the aim of studying special English for most of the students is to pass the final examination. 
In addition, the characteristic of mechanical special English is boring content, more terminology and large vocabulary. The course contents of special English are very much behind the times. The contents are the fundamentals of manufacturing engineering, such as engineering materials, heat treatment of metals, casting processes, metal cutting, grinding, surface engineering, turning, drilling, milling and conventional machining processes. Many students think special English learning is just comparison study between English and Chinese. Their interest in learning special English will be lost as time passes. After the special English course is finished, some students still don't understand some common special terms and idioms.

\section{Teaching Methods Problems}

Teaching methods of mechanical special English are traditional currently. The class is still dominated by the teachers lecturing on knowledge according to the textbook content, while the students are passive knowledge receivers without a variety of classroom activities[13]. During the whole process, the students' subjective initiative and learning enthusiasm are restricted, and the students' interest in learning the special English course is reduced greatly.

\section{The Evaluation Problems}

In many universities of our country, one teacher himself takes the special English course. When the final examination is coming, the teacher gives tests. In general, he selected some English paragraphs from the teaching materials and required students to translate them into Chinese. The types of written examination are too monotonous. This cann't meet the assessment requirements of comprehensive ability in listening, speaking, reading, writing and the expansion of the special knowledge, etc.

\section{Ideas for Special English Teaching Reform}

\section{A. Improve Teachers' Comprehensive Special Ability}

The special English teachers should be with high comprehensive quality. They should be proficient in mechanical professional knowledge, have good spoken English and the solid English background. They must lecture in English fluently and understand disciplinary knowledge according to English thinking habits. They should explain and answer questions and guide students to carry out inquiry-based learning in English. Most of the students who master basic English knowledge have passed the College English Test Band 4. English has become a service tool in the mechanical fields. So it sets a high standard for special English teachers. Most of the mechanical specialized English teachers understand professional knowledge, but their basic English is not solid. So it is important for them to be trained in the basic skills of listening, speaking, reading, writing, translating and English teaching methods. Some teachers can be trained abroad to learn more typical special English if condition permits[14]. Advanced experience and basic theory of special English teaching can be released in the special column of college journal to improve the teaching ability of special English teachers.

\section{B. Improving Teaching Methods}

The teaching activities should be conducted according to the language features of special English. The teachers should prioritize and highlight the key points while teaching. The author thinks that this can be divided into four steps. The first step is to make the students familiar with the style of special English courses through the introduction, reading and comparison. The second step is to review all kinds of nouns, pronouns, verbs and their variants on the basis of mastering grammar. With the aid of reading and teaching, the students' vocabulary was further expanded. Meanwhile, the students must be familiar with the special vocabulary and terms and their usage. The teachers should encourage their students to pay attention to the important effect of vebs, prepositions and conjunctions in English. The students also learn the relation and distinction between English idioms and special expression methods in special English. The third step is to pay attention to explain some grammatical phenomenon in special English studying and solve some problems encountered in learning[15]. The fourth step is to help the students to master some basic theories, methods and skills in reading, understanding and translating of special English. The emphasis should be on reading comprehension and translation English into Chinese[10].

The fourth step is the most crucial step in the process of special English teaching. But the teacher should depend on the concrete situation and needs and make the corresponding decisions. Reading comprehension and translation are very important in the process of special English teaching. Reading with proficiency will benefit understanding[11][12]. Only on the basis of reading comprehension, through the correct translation, the meaning of the originals can be expressed and the thought, culture and technology communication between different countries and languages can be achieved. So it is important to pay attention to reading comprehension and translation to improve the teaching quality of special English. In practical teaching, aiming at the concrete conditions of students, interactive teaching methods should be adopted. The original text should be translated by the students themselves. The teaching materials may be divided into several sections which are translated by several students. While the teacher should analyze and explain the translations in stages to guide the students translate the words and grammars correctly. During this process, the teacher points out the difficult and wrong translations and correct them, thus interpreting training is necessary to the students. Translation is a creative process[13].

\section{Improving Students' Learning Initiative}

Interest is the best teacher and it's also promise of study on one's own initiative. In the teaching process, the teacher should pay attention to improve the students' activeness and enthusiasm in learning mechanical special English. This is the key to improve the students' learning initiative. The teacher 
should seize the change of the sophomore students who are gradually interested in special knowledge. Then he can adjust teaching content and introduce some special knowledge under the condition of performing teaching tasks prescribed by the syllabus of the department[14]. The author has taken special English course for several years and found that the students are interested in the latest high-tech special knowledge. So the author lecture on computer numerical control, industrial robot, virtual manufacturing, networked manufacturing and intelligent manufacturing, etc.. This can stimulate the students' in learning special English, also can make students know about special knowledge. Thus it will benefit learning other courses.

In addition, the reverse thinking method can be adopted to guide the students to pay attention to learn special English. For example many machine tools are imported from America and England. The instructions and operating keyboard are English marking. So we must read the instructions and know the function of each key on the keyboard. Then the machine tool can be operated properly and qualified parts be made.

\section{Developing the Bilingual Teaching}

Currently, someone argues that bilingual teaching should be implemented in the universities of our country. The author thinks it is necessary. The bilingual teaching can enrich the students' vocabulary and will help in special English learning. But it is very important to improve the teachers' English level and to compile the proper bilingual teaching materials for developing the bilingual teaching effectively. College English teaching cannot be competent to cultivate communication ability of special English. Therefore the special courses' bilingual education is of great significance. In combination with a variety of modern educational model, the students' interest in learning will be stimulated[15].

\section{E. Comprehensive Evaluation}

A rational appraisal system should be made and executed strictly to improve the teaching quality of mechanical special English. A relatively effective way is to combine homeworks and the final examination, together with the basic knowledge and application abilities. The homework grade includes class discussion, paper writing, grammar and vocabulary review, ect.. The final examination grade consists of oral and written examination, the percentage of which depends on the subject being taught. The oral examination should be made according to the characteristic of mechanical specialty. The written examination mainly includes translating English paragraphs into Chinese and writing English abstract. The students' reading ability can be measured according to the evaluation system. Also it can embody the students' level of listening, speaking, reading, writing and translating. Thus the students' ability of expressing special knowledge in English and innovation can be assessed fully. But the key issue is implementing the appraisal system from beginning to end and making it a prescriptive and operational guideline. The final evaluation items are shown in Table 2 in our school over the last five years. Table 2 shows the evaluation items are becoming more and more comprehensive in our school over the last five years. The students' comprehensive ability is improved gradually.

\section{Conclusion}

It can be seen from the above analysis that exploration on teaching reform in mechanical special English is the needs of the development of social economy. Also it is the requirements of cultivating applied mechanic and technical talents. The existing problems such as textbook, faculty, course construction and management still need to further explore.

Table 2. Evaluation Items over the last five years

\begin{tabular}{|c|c|c|c|c|c|}
\hline Evaluation Items & 2010 & 2011 & 2012 & 2013 & 2014 \\
\hline English-Chinese Translation & $80 \%$ & $70 \%$ & $75 \%$ & $70 \%$ & $65 \%$ \\
\hline Chinese-English Translation & $5 \%$ & $5 \%$ & $5 \%$ & $5 \%$ & $5 \%$ \\
\hline $\begin{array}{c}\text { Explaining Acronyms in } \\
\text { English and Chinese }\end{array}$ & $5 \%$ & $5 \%$ & $3 \%$ & $5 \%$ & $5 \%$ \\
\hline Answer questions in English & 0 & $5 \%$ & $3 \%$ & $3 \%$ & $5 \%$ \\
\hline Writing & 0 & $5 \%$ & $5 \%$ & $5 \%$ & $5 \%$ \\
\hline Listening Comprehension & 0 & $5 \%$ & $2 \%$ & $5 \%$ & $5 \%$ \\
\hline Speaking test & $5 \%$ & $5 \%$ & $5 \%$ & $5 \%$ & $5 \%$ \\
\hline Reading Comprehension & $5 \%$ & 0 & $2 \%$ & $2 \%$ & $5 \%$ \\
\hline
\end{tabular}

As China's machinery manufacturing industry towards the development of informationization and globalization, the responsibility of universities which cultivate manufacturing excellence is very important. So this requires the mechanical specialized English teachers emancipate their minds and establish a well-formed concept of education to cultivate applied talents. Although mechanical special English learning is a long-term accumulation process, in the teaching practice the teacher should accept all kinds of education and teaching research results, make up proper teaching program based on the characteristic of teaching object. The application of mechanical special English can promote the students' study and vice versa. This may obtain expected training results during the period of class hours. Our special English teachers must emphasize that special English teaching should be changed from examination-oriented education to qualityorientated education through changing the education ideas and carrying out teaching reform and innovation. We should follow the principle of quality education and cultivate students' creative spirit and ability. Only so, we can finish our historical mission. The author put forward several measures to improve the English learning, aiming to the current mechanical special English teaching situation in many universities of our country. In this way, the students can gain advanced knowledge and information in the field of machinery and lay a solid foundation for employment and personal development.

\section{Acknowledgment}

The teaching research work was supported by applicationoriented talents cultivation characteristic universities key construction major projects. 


\section{References}

[1] M. -Y. Liu, "Application of information technology in college English teaching reform," Proceedings-2010 International Conference on Artificial Intelligence and Education, pp. 81-84, October 2010.

[2] F. Chang, "Research on college English teaching reform under the guidance of ESP," Journal of Hubei University of Economics (Humanities and Social Sciences), vol. 11, no. 7, pp. 202-203, July 2014.

[3] Y. Zhang, P. Wu, "College-English-teaching reform under the perspective of general education," Lecture Notes in Electrical Engineering, vol. 163 LNEE, pp. 561-568, 2013.

[4] D. -G. Li, V. Edwards, "English language teaching and educational reform in Western China: A knowledge management perspective," System, vol. 44, pp. 88-101, Dec 2014.

[5] S. -Y. Huan, T. Yan, "The Reform of Professional English Teaching in the Major of Electronic Information," 2nd International Conference on Education and Educational Technology (EET 2011), vol. 108, pp. 217222, Oct 2011.

[6] W. Jiang, W. -L. Hu, F. Yuan, "Reform and practice of professional English teaching," ETP/IITA Conference on Telecommunication and Information (TEIN 2010), pp. 73-75, Jun 2010.

[7] D. Hayes, "Language learning, teaching and educational reform in rural Thailand: an English teacher's perspective," ASIA PACIFIC JOURNAL OF EDUCATION, vol. 30, no. 3, pp. 305-319, 2010.
[8] L. Leisyte, J. Enders, H. de Boer, "The balance between teaching and research in Dutch and English universities in the context of university governance reforms," HIGHER EDUCATION, vol. 58, no. 5, pp. 619635, NOV 2009.

[9] F. Wang, "English teaching reform based on major-orientation," Journal of Hubei University of Economics (Humanities and Social Sciences), vol. 11, no. 7, pp. 190-199, July 2014.

[10] T. Lu, "Research on oral special English teaching reform of logistics," Journal of Hubei TV University, vol. 34, no. 7, pp. 039-040, July 2014.

[11] W. Guo, "Exploration on mechanical English teaching reform," Journal of $X i$ 'an Aerotechnical College, vol. 25, no. 5, pp. 78-80, September 2007.

[12] F. -H. Yin, T. -J. Liu, "Probing into mechanical English teaching of undergraduates," Journal of Changzhou Institute of Technology (Social Science Edition), vol. 26, no. 1/2, pp. 162-164, April 2008.

[13] J. -J. Wei, "Instructional Practice and Exploration of Special English Teaching for Graduate Student in Mechanical Engineering Specialties," Higher Education Forum, no. 7, pp. 84-86, July 2009.

[14] Z. Wang, L. Lei, "Investigation and Practice of the Reform of Special English Teaching of Science and Engineering," Journal of Higher Education Research, vol. 33, no. 1, pp. 104-106, March 2010.

[15] J. Dan, "Research on education and teaching reform based on social needs," Lecture notes in Electrical Engineering, vol. 163, LNEE, pp. 1335-1340, 2013. 